\title{
PEMBERDAYAAN PETANI JAGUNG OLEH STAKEHOLDERS DI NAGARI KATAPING KECAMATAN BATANG ANAI KABUPATEN PADANG PARIAMAN
}

\section{Deni Ardila}

\author{
Jurusan Administrasi Publik, Fakultas Ilmu Sosial, Universitas Negeri Padang \\ E-mail: deniardila86@gmail.com
}

\section{Fitri Eriyanti}

Jurusan Administrasi Publik, Fakultas Ilmu Sosial, Universitas Negeri Padang E-mail: fitri.eriyanti@ fis.unp.ac.id

\begin{abstract}
The purpose of this study was to determine the inhibiting factors and forms of empowerment of corn farmers by Stakeholders in Nagari Kataping Batang Anai District Padang Pariaman Regency. The backround of this research is that there are still many nagari Kataping communities who do not yet know how to process corn after harvest. This research uses qualitative research methods with descriptive type. The technique of this research is purposive sampling. The informants of this guidelines the form of structured questions and documentation. Data validity test in this study uses data source triangulation techniques because the comparison and back-checking of the degree of information obtained through different sources. Data analysis techniques throught three stages, namely the stage of data reduction, the stage of data presentation, and the stage of drawing conclusions. The results of this study are the forms of empowerment of corn farmers by Stakeholders and the inhibiting factors for the cultivation of corn farmers by Stakeholders in the nagari Kataping Kecamatan Batang Anai Kabupaten Padang Pariaman.
\end{abstract}

Keywords: Community empowerment, empowering farmers, corn farmers

How to Cite: Deni Ardila dan Fitri Eriyanti. 2019. Pemberdayaan Petani Jagung Oleh Stakeholders di nagari Kataping Kecamatan Batang Anai Kabupaten Padang Pariaman. 3(2): pp. 31-44. DOI: https://doi.org/10.24036/jess/vol3-iss2

\section{Pendahuluan}

Pemberdayaan merupakan upaya untuk memberikan kemampuan dan kesempatan kepada sekelompok masyarakat (miskin) untuk mampu dan berani bersuara (voice) atau menyuarakan pendapat, ide, atau gagasan-gagasannya, serta kemampuan dan keberanian untuk memilih (choice) sesuatu (konsep, metoda, produk, tindakan, dan lain sebagainya Worl Bank dalam Poerwoko dan Totok Mardikanto (2017). Sejalan dengan hal itu menurut Poerwoko dan Totok Mardikanto (2017) pemberdayaan dapat 
pula diartikan sebagai upaya peningkatan kemampuan masyarakat (miskin, marjinal, terpinggirkan) untuk menyampaikan pendapat dan atau kebutuhannya, pilihannya, berpatisipasi, bernegosiasi, mempengaruhi dan mengelola kelembagaan masyarakatnya secara bertanggung-gugat (accountable) demi perbaikan kehidupannya. Berdasarkan Undang-undang Republik Indonesia No 19 Tahun 2013 Pasal 1 Ayat 2 Tentang Perlindungan dan Pemberdayaan Petani bahwasanya pemberdayaan petani adalah segala upaya untuk meningkatkan kemampuan petani untuk melaksanakan usaha tani yang lebih baik melalui pendidikan dan pelatihan, penyuluhan dan pendampingan, pengembangan sistem dan sarana pemasaran hasil pertanian, konsolidasi dan jaminan luasan lahan pertanian, kemudahan akses ilmu pengetahuan, teknologi dan informasi, serta penguatan kelembagaan petani.

Peranan penting dari sektor pertanian di dalam perekonomian Indonesia terutama dalam bentuk penyediaan kesempatan kerja da konsribusinya terhadap pembentukan PDB dan ekspor Tambunan dalam Umbu Maramba, (2018). Pangan merupakan istilah yang penting bagi pertanian karena secra hakiki pangan adalah salah satu kebutuhan paling mendasar di dalam kehidupan manusia. Tingkat kesejahteraan petani dapat digambarkan dengan pendapatan yang diperoleh. Menurut Suratiyah dalam Umbu Maramba, (2018) besarnya pendapatan dipengaruhi oleh faktor internal dan faktor eksternal. Adapun faktor internal yaitu partisipasi dan modal. Sedangkan faktor eksternal yaitu pemasaran hasil jagung setelah panen. Oleh karena itu tanaman jagung merupakan tanaman pokok kedua setelah padi, diusahan agar dapat membantu memenuhi kebutuhan pangan masyarakat Widjayanti (dalam Umbu Maramba, (2018).

Kabupaten Padang Pariaman merupakan sebuah Kabupaten yang terletak di Provinsi Sumatera Barat Indonesia. Kabupaten ini memiliki luas wilayah 1.328,79 km dan populasi 427.919 jiwa. Kabupaten Padang Pariaman memiliki 17 Kecamatan salah satunya adalah Kecamatan Batang Anai.Kecamatan Batang Anai banyak memiliki bidang pertanian salah satunya pertanian jagung.Produksi jagung di Kecamatan Batang Anai Kabupaten Padang Pariaman Sumatera Barat ini mencapai 23.150 ton per tahunnya. Kecamatan Batang Anai memiliki 8 nagari salah satunya adalah nagari Kataping yang merupakan banyak masyarakatnya bertani jagung.

Berdasarkan data awal yang penulis dapatkan dari Kantor Walinagari Kataping Kecamatan Batang Anai Kabupaten Padang Pariaman bahwa banyak terdapat masyarakat bertani jagung.Secara keseluruhan di Nagari Kataping Kecamatan Batang Anai Kabupaten Padang Pariaman terdapat 412 kepala keluarga yang bertani jagung.Diketahui luas lahan yang digunakan untuk bertani jagung cukup luas dengan rata-rata hampir $2 \mathrm{Ha}$ per orang. Masyarakat Nagari Kataping masih banyak yang belum tahu bagaimana cara mengolah jagung. Masyarakat setempat hanya memanfaatkan jagung untuk kosumsi sendiri serta pada saat setelah panen masyarakat menjual hasil panen ke pedagang pengumpul untuk dijadikan pakan ternak dan harga jagung juga ditentukan oleh pedagang pengumpul. 
Sesuai dengan wawancara yang penulis lakukan dengan Bapak Alwis Jaya selaku Walinagari Kataping pada tanggal 27 Februari 2019 mengatakan bahwa pengolahan jagung memang belum ada dikarenakan dana nagari lebih diperuntukkan untuk memperbaiki irigasi-irigasi saluran air sawah dan pembangunan jalan. Sedangkan setelah panen masyarakat menjual hasil panen ke pedagang pengumpul untuk dijadikan pakan ternak dan masalah harga diserahkan kepada petani dan pedagang pengumpul. Wawancara selanjutnya yang penulis lakukan dengan Ondon seorang petani jagung pada tanggal 14 Maret 2019 yang mengatakan bahwapetani jagung di Nagari Kataping melakukan kerjasama dengan pedagang pengumpul. Mereka meminjam modal kepada pedagang pengumpul dengan syarat hasil panen dijual kepada mereka yang meminjamkan modal. Petani jagung berharap pemerintah juga memberikan bantuan berupa pupuk tidak hanya bantuan bibit saja.

Hal senada juga disampaiakan oleh Bapak Indra selaku Kepala Seksi Produksi Tanaman Pangan dan Hortikultural di Dinas Pertanian dan Ketahanan Pangan Kabupaten Padang Pariaman pada tanggal 18 Maret 2019 mengatakan bahwa perannya dalam meningkatkan pengetahuan dan keterampilan petani jagung, memberikan bimbingan secara langsung melalui penyuluh pertanian di lapangan serta memfasilitasi kegiatan-kegiatan yang berkaitan dengan tanaman jagung. Dalam 4 tahun terkahir ini bantuan yang berupa pupuk di Nagari Kataping memang belum ada dikarenakan anggaran dari pusat hanya berupa bantuan benih. Selanjutnya Wawancara dengan Ibu Samsi Warmis selaku Penyuluh Pertanian Lapangan di Nagari Kataping Kecamatan Batang Anai pada tanggal 20 Maret 2019 mengatakan bahwaprogram dari Penyuluh Petanian Kecamatan adalah untuk mengetahui cara pengolahan jagung, cara budidaya jagung, jarak tanam jagung, serta bagaimana pemupukan jagung. Kendala dalam pemberdayaan petani jagung terletak pada modal dan pemasaran jagung setelah panen. Berdasarkan uraian permasalahan yang dihadapi dalam pemberdayaan petani petani jagung oleh Stakeholders yang perlu dilakukan adalah dengan menjalin hubungan kerjasama antar Stakeholders mengenai pemberdayaan petani jagung di Nagari Kataping Kecamatan Batang Anai Kabupaten Padang Pariaman serta memberikan pemahaman akan tugas masing-masing dari Stakeholders.

Berdasarkan permasalahan tersebut maka dapat dirumuskan beberapa permasalahan diantaranya: 1) Bagaimana bentuk pemberdayaan petani jagung oleh Stakeholders di Nagari Kataping Kecamatan Batang Anai Kabupaten Padang Pariaman; 2) Apa saja faktor penghambat yang di hadapi oleh Stakeholders dalam pemberdayaan petani jagung di Nagari Kataping Kecamatan Batang Anai Kabupaten Padang Pariaman, sehingga dapat menjawab penelitian dengan judul penelitian "Pemberdayaan Petani Jagung Oleh Stakeholders di Nagari Kataping Kecamatan Batang Anai Kabupaten Padang Pariaman”. 


\section{Tinjauan Kepustakaan}

\section{Pemberdayaan}

Pemberdayaan menurut Poerwoko dan Totok Mardikanto (2017) mengandung arti kesejahteraan atau perbaikan mutu hidup setiap individu dan juga masyarakat baik antara lain dalam arti: perbaikan ekonomi terutama dalam kecukupan pangan, perbaikan kesejahteraan sosial, kemerdekaan dari segala bentuk penindasan, keamanan terjamin, serta terjaminnya hak asasi manusia yang bebas dari segala takut dan dari segala kekhawatiran. Sedangkan menurut Soleh Chabib (2014) mengungkapkan pemberdayaan untuk memperbaiki kekuatan yang yang berbasis pada kualitas kehidupan atau daya yang mereka miliki sendiri, melalui optimalisasi daya serta pada peningkatan posisi tawar yang mereka miliki. Artinya, pemberdayaan harus menempatkan kekuatan masyarakat sebagai modal utama, sementara itu pihak luar seperti pemerintah dan lembaga swadaya masyarakat dipandang sebagai modal pelengkap. Selanjutnya Djohani dalam Suryono Haryono (2013) mengungkapkan bahwa pemberdayaan adalah suatu proses pemberian kekuasaan atau daya kepada pihak yang lemah, dan mengurangi suatu kekuasaan kepada pihak yang terlalu berkuasa sehingga terjadinya keseimbangan.

Menurut Poerwoko dan Totok Mardikanto (2015) pemberdayaan masyarakat merupakan suatu upaya dalam peningkatan harkat dan martabat lapisan masyarakat yang di dalam kondisi tidak mampu untuk melepaskan diri dari kemiskinan dan ketertinggalan. Dengan kata lain, pemberdayaan merupakan memampukan dan memandirikan suatu masyarakat. Dalam pemberdayaan tersebut dapat kita lihat ada tiga sisi upaya, diantaranya: 1) Menciptakan suasana atau iklim yang memungkinkan potensi suatu masyarakat berkembang; 2) Memperkuat potensi atau daya yang dimiliki oleh masyarakat; 3) Memberdayakan berarti melindungi, melindungi berarti tidak mengisolasi atau menutupi dari interaksi, karena hal tersebut justru akan memperkecil yang kecil dan mengabaikan yang lemah. Dapat dipahami bahwa, pada hakikatnya pemberdayaan merupakan penciptaan suasana yang memungkinkan masyarakat untuk berkembang. Hal ini didasarkan bahwa tidak ada masyarakat yang sama sekali tidak memiliki daya/kekuatan.

Dalam pemberdayaan Dahama dan Bhatnagar dalam Poerwoko dan Totok Mardikanto (2017) memiliki prinsip-prinsip pemberdayaan sebagai berikut: 1) Minat dan kebutuhan; 2) Organisasi masyarakat bawah; 3) Keragaman budaya; 4) Perubahan budaya; 5) Kerjasama dan partisipasi; 6) Demokrasi dalam penerapan ilmu; 7) Belajar sambil bekerja; 8) Penggunaan metoda yang sesuai dengan kondisi lingkungan fisik 9) Kepemimpinan; 10) Spesialis yang terlatih; 11) Segenap keluarga; 12) Kepuasan. Dari prinsip-prinsip tersebut dikaitkan dengan pemberdayaan petani jagung oleh Stakeholders di Nagari Kataping pada point minat dan kebutuhan, serta belajar sambil bekerja akan berjalan efektif jika mengacu pada minat dan kebutuhan 
masyarakat. Dalam hal ini harus benar-benar dikaji apa yang paling dibutuhkan masyarakat terkhusus untuk petani jagung di Nagari Kataping.

Tujuan dari pemberdayaan masyarakat adalah untuk meningkatkan harkat dan martabat kehidupan manusia, dengan lain kata untuk meningkatkan kualitas hidup manusia Soleh Chabib, (2014). Poerwoko dan Totok Mardikanto (2017) tujuan pemberdayaan mencakup upaya perbaikan diantaranya: 1) Perbaikan pendidikan; 2) Perbaikan aksesibilitas; 3) Perbaikan tindakan; 4) Perbaikan kelembagaan; 5) Perbaikan usaha; 6) Perbaikan pendapatan; 7) Perbaikan lingkungan; 8) Perbaikan kehidupan; 9) Perbaikan masyarakat. Dikaitkan dengan pemberdayaan petani jagung di Nagari Kataping oleh Stakeholders akan efektif jika dalam pencapaian tujuan pemberdayaan masyarakat diharapkan dapat memperbaiki usaha termasuk pengembangan jejaring dan kemitraan usaha yang dilakukan oleh para Stakeholders terhadap petani jagung seperti pengolahan jagung menjadi makanan olahan dodol jagung, stick jagung, tempe jagung dan mie jagung.

Menurut Pranaka dan Prijono, (1996) merumuskan 3 (tiga) bentuk pemberdayaan masyarakat diantaranya:

1. Bentuk Inisial, merupakan bentuk pemberdayaan dari pemerintah, oleh pemerintah, dan untuk rakyat (masyarakat).

2. Bentuk Partisipatoris, merupakan bentuk pemberdayaan masyarakat dari pemerintah bersama masyarakat, oleh pemerintah bersama masyarakat, dan untuk rakyat (masyarakat).

3. Bentuk Emansipatif, merupakan bentuk pemberdayaan masyarakat dari rakyat, untuk rakyat, dan di dukung oleh pemerintah bersama masyarakat

Pemberdayaan masyarakat memiliki beberapa lingkup yang disebut sebagai Tri Bina oleh Poerwoko dan Totok Mardikanto (2013) yaitu: 1) Bina manusia, merupakan upaya pertama yang harus diperhatikan dalam pemberdayaan masyarakat. Adapun upaya kegiatan yang termasuk dalam bina manusia diantaranya pengembangan kapasitas individu, kapasitas entitas/kelembagaan; 2) Bina usaha, mencakup: pemilihan komoditas dan jenis usaha, kelayakan studi dan perencanaan bisnis,pembentukan badan usaha, perencanaan investasi, produksi dan operasi, logistik dan finansial, penelitian serta pengembangan, pengelolaan sistem informasi bisnis, jejaring dan kemitraaan, dan sarana prasarana pendukung; 3) Bina lingkungan, merupakan pelestarian lingkungan yang sangat penting dalam usaha pembangunan berkelanjutan terhadap kegiatan atau investasi dan operasi.

\section{Pemberdayaan Petani}

Petani adalah seseorang yang bergerak di bidang pertanian, utamanya dengan cara melakukan pengolahan tanah dengan tujuan untuk menumbuhkan dan memelihara tanaman, dengan harapan untuk memperoleh hasil dari tanaman tersebut untuk digunakan sendiri ataupun menjualnya kepada orang lain Sukino (2013). Berdasarkan Undang-Undang Republik Indonesia Nomor 19 Tahun 2013 tentang Perlindungan \& Pemberdayaan Petani pada Pasal 1 Ayat 2 tertulis pengertian pemberdayaan petani 
yang berbunyi "pemberdayaan petani adalah segala upaya untuk meningkatkan kemampuan petani untuk melaksanakan usaha tani yang lebih baik melalui pendidikan dan pelatihan, penyuluhan dan pendampingan, pengembangan sistem dan sarana pemasaran hasil pertanian, konsolidasi dan jaminan luasan lahan pertanian, kemudahan akses ilmu pengetahuan, teknologi dan informasi, serta penguatan kelembagaan petani”. Petani perlu diberikan perlindungan serta pemberdayan supaya petani memiliki kapasitas untuk terus tumbuh dan berkembang menjadi lebih sejahtera.Secara keseluruhan dapat disimpulkan bahwa pemberdayaan petani adalah suatu usaha atau upaya untuk memberdayakan atau meningkatkan manusia (petani) untuk melakukan usaha tani yang lebih baik berupa kompetensi, wewenang, dan tanggung jawab dalam rangka meningkatkan kinerja pertanian.

Menurut Sukino (2013) ada tiga hal yang harus diperhatikan dalam pemberdayaan petani diantaranya:

1. Pembangunan yang dilakukan oleh masyarakat tani harus demokrasi

2. Mengembangkan sistem partisipasi

3. Memberikan otonomi yang lebih luas terhadap masyarakat tani untuk membangun desanya.

Selanjutnya Sukino (2013) mengemukakan beberapa strategi dalam pemberdayaan masyarakat tani diantaranya:

1. Pemberdayaan petani melalui kelas kemampuan kelompok.

2. Pemberdayaan petani melalui siklus kehidupan.

3. Pemberdayaan petani melalui jenis kelamin, yaitu kelompok wanita tani dan kelompok yang beranggotakan bapak-bapak tani, atau yang lazim disebut kelompok tani pria.

4. Pemberdayaan melalui jumlah keluarga, jumlah keluarga sangat berpengaruh terhadap pemberdayaan masyarakat, karena semakin banyaknya jumlah anggota keluarga yang ditanggung, menyebabkan makin sulit bagi petani untuk mengembangkan usaha taninya.

5. Pemberdayaan melalui jenjang kelompok, artinya kelompok tani yang beranggota remaja, usia antara 20 an tahun yang disebut kelompok pemuda tani atau disebut kelompok taruna tani.

6. Pemberdayaan petani melalui komoditas utama (pokok), kehidupan petani sesuai dengan mata pencaharian yang ada di desa terdapat tiga kelompok, yaitu: (1) petani yang mengutamakan komoditas tertentu sebagai mata pencaharian pokok dengan usaha pokok beternak. (2) petani dengan mengutamakan komoditas tertentu seperti salak pondoh, padi sebagai mata pencaharian pokok, tetapi mempunyai sampingan sebagai pemelihara ternak. (3) petani yang mengubah mata pencaharian pertanian menjadi buruh bangunan dan lain-lain. 


\section{Petani Jagung}

Petani adalah seseorang yang bergerak di bidang pertanian, utamanya dengan cara melakukan pengolahan tanah dengan tujuan untuk menumbuhkan dan memelihara tanaman, dengan harapan untuk memperoleh hasil dari tanaman tersebut untuk digunakan sendiri ataupun menjualnya kepada orang lain Sukino (2013). Jagung merupakan makanan pokok kedua setelah padi di Indonesia. Jagung secara spesifik merupakan tanaman pangan yang sangat bermanfaat bagi kehidupan manusia ataupun hewan. Berdasarkan urutan bahan makanan pokok di dunia jagung menduduki urutan ketiga setelah gandum dan padi. Tanaman jagung hingga kini dimanfaatkan oleh masyarakat dalam bentuk berbagai penyajian menurut Ermanita dalam Siska, dkk. (2018). Selanjutnya menurut Zubachtiroddin dalam Abd. Gaffar Tahir (2017) jagung merupakan tanaman pangan penting kedua setelah padi mengingat fungsinya yang multiguna dan merupakan pangan penyumbangterbesar kedua terhadap Produk Domestik Regional Bruto (PDRB) setelah padi. Selain itu jagung menjadi penarik bagi pertumbuhan industri hilir di dalam sistem dan usaha agribisnis Ditjentan dalam Tahir dan Suddin (2017)

Produksi jagung di Indonesia masih relatif rendah dan masih belum dapat memenuhi kebutuhan konsumen yang cenderung terus meningkat. Produksi jagung nasional belum mampu mengimbangi permintaan yang sebagian dipacu oleh pengembangan industri pakan dan pangan menurut Budiman dalam Tahir dan Suddin (2017). Permintaan akan bahan pangan di Indonesia dari tahun ketahun semakin meningkat terutama bahan pangan utama seperti padi jagung, dan kedelai. Jagung adalah salah satu bahan pangan terpenting karena merupakan sumber karbohidrat kedua setelah padi. Selain sebagai bahan pangan, jagung juga merupakan komoditas tanaman pangan setelah padi. Komoditas ini juga dapat digunakan sebagai pakan ternak dan bahan baku industri seperti industri etanol menurut Purwono dan Hartono dalam Tahir dan Suddin (2017).

Berdasarkan uraian di atas dapat disimpulkan bahwa, petani jagung adalah seseorang yang bergerak di bidang pertanian, utamanya dengan cara melakukan pengolahan tanah dengan tujuan untuk menumbuhkan dan memelihara tanaman, dengan harapan untuk memperoleh hasil dari tanaman tersebut untuk digunakan sendiri ataupun menjualnya kepada orang lain serta juga dapat digunakan sebagai pakan ternak dan bahan baku industri.

\section{Metode Penelitian}

Dalam penelitian ini menggunakan metode kualitatif dengan tipe deskriptif dimana menggambarkan pengamatan, tindakan, orang dan pembicaraan yang diperoleh selama di lapangan.Lokasi penelitian ini bertempat di Nagari Kataping Kecamatan Batang Anai Kabupaten Padang Pariaman karena di Nagari ini terdapat banyak masyarakat yang bertani jagung dan belum terdapat pengolahan jagung kedalam bentuk yang bernilai jual tinggi. Teknik yang digunakan dalam pemilihan penelitian 
ini adalah teknik Purposive Sampling, yaitu pemilihan terhadap sumber data orang yang diwawancarai dengan pertimbangan dan tujuan tertentu. Informan dalam penelitian ini yaitu: Dinas Pertanian dan Ketahanan Pangan Kabupaten Padang Pariaman, Balai Penyuluh Pertanian Kecamatan Batang Anai, Walinagari Kataping, kelompok tani jagung di Nagari Kataping Kecamatan Batang Anai Kabupaten Padang Pariaman.

Teknik pengumpulan menggunakan alat pedoman wawancara peneliti berupa pertanyaan terstruktur, wawancara, dan dokumentasi.Untuk uji keabsahan data menggunakan teknik trianggulasi sumber dan teknik karna perbandingan dan pengecekan balik derajat informasi yang diperoleh melalui sumber berbeda. Teknik analisis data melalui tiga tahap: tahap reduksi data, penyajian data, dan tahap penarikan kesimpulan verifikasi.

\section{Hasil Penelitian dan Pembahasan}

Berdasarkan hasil penelitian yang telah selesai dilakukan bahwasanya peneliti akan menjawab rumusan masalah yang telah dipaparkan sebelumnya maka dapat ditemukan beberapa hasil diantaranya: Bentuk pemberdayaan petani jagung oleh Stakeholders di Nagari Kataping. Serta faktor penghambat pemberdayaan petani jagung oleh Stakeholders di Nagari Kataping Kecamatan Batang Anai Kabupaten Padang Pariaman.

1. Bentuk pemberdayaan petani jagung oleh Stakeholders di Nagari Kataping Kecamatan Batang Anai Kabupaten Padang Pariaman.

Berdasarkan hasil penelitian yang penulis lakukan di lapangan menunjukkan bahwa bentuk pemberdayaan petani jagung oleh Stakeholders di Nagari Kataping Kecamatan Batang Anai berupa dalam bentuk pemberian bantuan bibit jagung, adanya pertemuan dan pelatihan kepada kelompok tani serta adanya pemeliharaan tanaman jagung terkait dengan bagaimana budidaya jagung mulai dari cara pembibitan jagung, cara tanam jagung, pemupukan jagung, dan cara pemberian obat-obatan pada tanaman jagung sampai pada masa panen jagung.

a. Bentuk Inisial

Bentuk inisial pemberdayaan petani jagung di Nagari Kataping adalah berupa bentuk pemberian bantuan bibit jagung, adanya pertemuan dan pelatihan serta adanya pemeliharaan tanaman jagung terkait dengan bagaimana budidaya jagung mulai dari cara pembibitan, cara tanam, hingga pemupukan jagung, dan cara pemberian obat-obatan pada tanaman jagung sampai pada masa panen jagung. Dengan adanya bentuk pemberdayaan terhadap petani jagung dalam bentuk inisial yaitu dalam bentuk peningkatan sumberdaya manusia dengan cara diadakan pelatihan guna untuk meningkatkan pengetahuan masyarakat tentang pengolahan jagung. 
Poerwoko dan Totok Mardikanto (2017) menyatakan tujuan pemberdayan meliputi berbagai upaya perbaikan kehidupan, tindakan, kelembagaan, usaha serta perbaikan pendapatan masyarakat Nagari Kataping. Adanya bentuk pelatihan dan pembinaan ini tentu akan berimbas terhadap membaiknya pendapatan petani jagung. Sejalan dengan hasil penelitian Citra Ayu Dewi, dkk (2017) dari hasil penelitian tersebut mengatakan bahwa melalui kegiatan KKN-PPM jagung dapat dikembangkan menjadi produk olahan diversifikasi yang bernutrisi dan bernilai jual tinggi dibandingkan dengan bentuk segarnya, misalnya diolah menjadi tempe jagung, dodol jagung, susu jagung dan mie jagung dan tentunya pasti mempunyai masa simpan lebih panjang jika dikemas dengan baik. Selain itu, dengan adanya diversifikasi olahan jagung menjadi berbagai produk diharapkan dapat menambah deretan perbendaharaan hasil olahan jagung dan dapat meningkatkan konsumsi jagung untuk pangan. Hal ini tentunya akan memberikan multiplier effect bagi petani jagung, sehingga memberikan jaminan terserapnya produksi jagung oleh industri pangan dan meningkatnya pendapatan masyarakat serta pengetahuan tentang pengolahan jagung setelah panen di daerah Labuapi.

Bentuk pemberdayaan Inisial di Nagari Kataping ini guna meningkatkan pengetahuan dan keterampilan masyarakat dalam bercocok tanam jagung sehingga hasil panen yang di dapatkan memuaskan. sehingga dapat meningkatkan pendapatan masyarakat petani yaitu dengan cara pelatihan budidaya jagung mulai dari pembibitan sampai masa panen jagung. Agar pemberdayaan ini berjalan dengan yang di inginkan maka langkah dalam melakukan bentuk pemberdayaan terhadap petani jagung di Nagari Kataping adalah dengan bentuk pemberdayaan Inisial. Dimana petani di bina dan di latih mengenai cara bercocok tanam jagung yang baik mulai dari pembibitan jagung, pemberian pupuk pada jagung sampai pada pembinaan setelah panen.

b. Bentuk Partisipatoris

Pemberdayaan di Nagari Kataping berupa adanya penerapan teknologi guna untuk membantu masyarakat petani dalam mengolah lahan pertaniansejalan dengan penelitian yang dilakukan oleh Suandi, dkk (2011) dengan hasil bahwa dengan cara memberikan keterampilan teknologi budidaya pertanian organik berbasis trikolimtan dengan tujuan memberikan keterampilan teknologi dalam pembuatan trichokompos berbasis trikolimtan, keterampilan teknologi budidaya pertanian organik berbasis trikolimtan, memberikan alternatif mata pencaharian bagi kelompok tani, dan bagi kelompok tani ditumbuhkembangkan jiwa kewirausahaan secara mandiri.

Bentuk pemberdayaan terhadap petani jagung di Nagari Kataping dengan adanya penerapan teknologi guna untuk membantu masyarakat tani dalam mengolah jagung dapat meningkatkan keberhasilan pertanian yang 
baik, dan dapat meningkatkan pendapatan petani jagung. Selanjutnya temuan penelitian ini juga sejalan dengan penelitian yang dilakukan oleh Citra Ayu Dewi, dkk (2017) mengatakan bahwa kegiatan pemberdayaan petani jagung melalui usaha pengembangan diversifikasi produk olahan olahan jagung diterapkan melalui penerapan teknologi pengembangan diversifikasi produk olahan jagung yang ringan dan mudah dipubliskan oleh petani jagung.

c. Bentuk Emansipatif

Adalah berupa diadakannya sosialisasi dan pertemuan dengan petani jagung. Temuan penelitian ini sejalan dengan penelitian yang dilakukan oleh Hubertus Ojan, dkk (2017) dengan hasil penelitian mengatakan bahwa dalam pemberdayaan petani jagung dilaksanakan dengan cara Penyuluhan dan sosialisasi diharapkan agar dapat menghasilkan sumberdaya produksi, prasarana pokok, modal kerja, disamping layanan umum lain yang dibutuhkan golongan penduduk miskin agar dapat turut serta dalam bentuk kegiatan ekonomi.

Selanjutnya temuan penelitian ini juga sejalan dengan penelitian yang dilakukan oleh Sumarlan, dkk (2012) yang mengatakan bahwa pihak perhutani melakukan penyuluhan melalui penyuluh swadaya yang diangkat dari ketua atau pengurus kelompok yang diatur dalam skema LMDH. Sedangkan perusahaan saprodi terutama jagung dan pupuk dengan mengangkat penyuluh swadaya dari ketua atau pengurus kelompok yang sekaligus difungsikan sebagai distributor atau agen pemasaran produk.Lalu sanggar kegiatan belajar (SKB) melakukan fungsi penyuluhan, yang dilakukan oleh para guru pamong.Perlu diketahui bahwa peran guru pamong melakukan pengajaran "kejar target" dipadukan dengan kegiatan pemberdayaan masyarakat seperti pembibitan sangon, budidaya ikan lele dan kambing etawa.

Bentuk pemberdayaan petani jagung akan berjalan dengan yang di inginkan jika kegiatan pemberdayaan dilakukan dengan adanya sosialisasi dari penyuluhan yang berskala oleh para penyuluh agar tercapainya kehidupan masyarakat yang lebih sejahtera.

2. Faktor penghambat pemberdayaan petani jagung oleh Stakeholders di Nagari Kataping Kecamatan Batang Anai Kabupaten Padang Pariaman.

Faktor penghambat merupakan faktor yang menghalangi suatu kegiatan organisasi baik itu dari dalam organisasi maupun dari luar organisasi.

a. Faktor internal, merupakan faktor yang menghambat dari dalam diri seseorang maupun organisasi. Dalam pemberdayan petani jagung di Nagari Kataping adapun yang menjadi faktor penghambat dari dalam adalah partisipasi dan modal. Terbatasnya modal yang dimiliki oleh petani jagung di Nagari Kataping menyebabkan petani jagung melakukan kerjasama dengan para tengkulak dengan cara meminjam modal untuk bertani dan pembayaran hutang dilakukan setelah panen. 
Beracuan pada prinsip-prinsip pemberdayaan masyarakat Dahama dan Bhatnagar dalam Poerwoko dan Totok Mardikanto (2017)mengungkapkan beberapa prinsip pemberdayaan masyarakat diantaranya: pemberdayaan dilakukan dengan kerjasama dan partisipasi. Artinya, pemberdayaan hanya akan efektif jika mampu menggerakkan partisipasi masyarakat untuk selalu bekerjasama dalam melaksanakan kegiatan pemberdayaan yang telah dirancang. Partisipasi sering sekali menjadi kendala dalam pemberdayaan petani jagung di Nagari Kataping dikarenakan kehadiran dari kelompok tani pada saat ada kegiatan pelatihan dan penyuluhan yang dilakukan oleh penyuluh pertanian.

Temuan penelitian ini sejalan dengan penelitian yang dilakukan oleh Adi Riyanto, dkk (2011) dengan hasil penelitian mengatakan bahwa partisipasi petani dalam pengelolaan hutan kemiri memberikan dampak positif terhadap keberlanjutan maanfaat hutan kemiri. Walaupun berdampak positif partisipasi petani dalam pengelolaan hutan kemiri memberikan kontribusi yang relatif kecil terhadap keberlanjutan manfaat hutan kemiri.

Selanjutnya aspek permodalan. Dalam melakukan usaha di bidang apapun, Modal menjadi bagian sangat penting agar usaha tersebut bisa berjalan dengan baik. Sejalan dengan penelitian yang dilakukan olehyangmengatakan bahwa tingkat keberdayaan masyarakat sekitar kawasan hutan lindung jompi masih rendah, hal ini disebabkan oleh rendahnya modal fisik (physical capital), modal manusia (human capital), kemampuan pelaku pemberdayaan, dan lemahnya proses pemberdayaan masyarakat. Dalam pemberdayaan petani jagung di Nagari Kataping oleh Stakeholders karena terbatasnya modal ini banyak petani jagung yang melakukan kerjasama dengan toke atau kios untuk meminjam modal dalam bertani jagung. Masalah permodalan bagi para petani merupakan hal yang sangat krusial. Kebijakan pemerintah dalam upaya meningkatkan pertumbuhan ekonomi diarahkan untuk meningkatkan produksi dan produktivitas hasil pertanian. Harapannya, tentu akan terjadi peningkatan produksi dan produktivitas hasil pertanian yang akan mendorong tumbuh dan berkembangnya sektor lain seperti industry dan jasa. Upaya untuk meningkatkan hasil pertanian, dipengaruhi oleh berbagai aspek. Salah satu aspek yang dapat berpengaruh pada keberhasilan upaya peningkatan hasil pertanian adalah partisipasi dan permodalan. Karena rendahnya aspek partisipasi dan permodalan akan mempengaruhi tingkat produktivitas bagi petani jagung rendahnya melakukan usaha di bidang apapun.

b. Faktor eksternal, merupakan faktor penghambat yang berasal dari luar kelompok atau organisasi. Dalam pemberdayaan petani jagung di Nagari Kataping yang menjadi faktor penghambat dari luar adalah pemasaran hasil setelah panen. Pembelian bibit jagung mahal pada saat menjual hasil panen murah dan untuk bahan-bahan dalam bertani jagung juga mahal. 
Temuan penelitian ini sejalan dengan penelitian yang dilakukan oleh Ni Made, dkk (2016) mengatakan bahwa faktor penting dalam perolehan pendapatan usahatani adalah harga. Harga jual yang tinggi bagi petani akan meningkatkan semangat petani untuk terus berusahatani. Seluruh petani merasa harga yang diberikan oleh pedagang pengumpul masih rendah, karena biaya total yang petani keluarkan untuk kegiatan usahatani semakin hari semakin meningkat. Penentuan harga oleh pedagang pengumpul memperlihatkan bahwa petani tidak memiliki posisi yang kuat untuk ikut menentukan harga jual jagungnya.

Salah satu faktor Eksternal yang mempengaruhi keberhasilan petani jagung di Nagari Kataping adalah harga. Semakin baik harga jagung yang diberikan maka petani cenderung lebih semangat untuk menjalankan usahataninya. Upaya dalam penilaian keberhasilan suatu usahatani dapat dilakukan evaluasi terutama dari sudut pandang ekonomi, salah satunya adalah pendapatan terhadap petani jagung.

\section{Penutup}

Berdasarkan hasil penelitian yang penulis lakukan di Nagari Kataping Kecamatan Batang Anai Kabupaten Padang Pariaman, maka penulis memberi kesimpulan bahwa:

1. Bentuk Pemberdayaan Petani Jagung di Nagari Kataping oleh Stakeholders dilakukan dalam bentuk pelatihan, pendampingan dan pembinaaan. Pelatihan dan pembinaan ini dilakukan secara berkelompok tentang bagaimana pemberian pupuk yang baik terhadap tanaman jagung dan pemberian bantuan bibit jagung terhadap petani jagung. Pelatihan dan pendampingan ini dimulai dari budidaya jagung dengan contoh bagaimana pembibitan jagung yang baik, penanaman jagung yang baik, serta pemberian obata-obatan pada jagung. Pemberdayaan ini dilakukan agar masyarakat petani jagung dapat meningkatkan pendapatan dan penambah ilmu pengetahuan mengenai cara bertanam jagung yang baik.

2. Faktor Penghambat dari Pemberdayaan Petani Jagung di Nagari Kataping Kecamatan Batang Anai adalah:

a. Terbatasnya modal yang dimiliki oleh petani jagung, sehingga banyak petani yang bekerjasama dengan toke atau kios-kios.

b. Partisipasi dari kelompok tani dalam mengikuti kegiatan penyuluhan dan pelatihan dari penyuluh sangatlah sedikit.

c. Pemasaran jagung setelah panen. 


\section{DAFTAR KEPUSTAKAAN}

Adi Riyanto. (2011). Model Peningkatan Partisipasi Petani Sekitar Hutan Dalam Pengelolaan Hutan Kemiri Rakyat. Jurnal Penelitian Sosial Dan Ekonomi Kehutanan, 8(3), 176-195.

Citra Ayu Dewi. (2017). Pemberdayaan Petani Jagung Melalui Pengembangan Usaha Diversifikasi Produk Olahan Jagung di Labuapi KAbupaten Lombok Barat. Jurnal Pengabdian Kepada Masyarakat IKIP Mataram, 2(3), 176-195.

Hubertus Ojan. (2017). Pemberdayaan Masyarakat Petani Jagung Berbasis Kelompok Usaha Tani dalam Meningkatkan Usaha Ekonomi Produktif (EUP) dikampung Marga Mulia, Kabupaten Merauke. 6(2), 78-88.

Ni Made. (2016). Kinerja Usahatani dan Motivasi Petani dalam Penerapan Inovasi Varietas Jagung Hibrida Pada Lahan Kering di Kabupaten Lombok Timur. Jurnal Ilmu Pemerintahan, Maret, 12(1), 31-42.

Poerwoko dan Totok Mardikanto. (2013). Pemberdayaan Masyarakat dalam Perspektif Kebijakan Publik. Bandung: Alfabeta.

Poerwoko dan Totok Mardikanto. (2015). Pemberdayaan Masyarakat dalam Kebijakan Publik. Bandung: Alfabeta.

Poerwoko dan Totok Mardikanto. (2017). Pemberdayaan Masyarakat dalam Perspektif Kebijakan Publik. Bandung: Alfabeta.

Pranaka dan Prijono. (1996). Pemberdayaan Konsep, Kebijakan dan Implementasi. Jakarta: Centre For Strategic And International Studies.

Siska, dkk. (2018). Analisis Pendapatan Usahatani Jagung Di Desa Wera Kecamtan Dolo Barat Kabupaten Sigi. Jurnal Pembangunan Agribisnis, 1(1).

Soleh Chabib. (2014). Dialektika Pembangunan dengan Pemberdayaan. Bandung: Fokusmedia.

Suandi. (2011). Pemberdayaan Masyarakat Melalui Pengembangan Pertanian Organik Berbasis Trikolimtan Di Kota Sungai Penuh Provinsi Jambi. Jurnal Pengabdian Kepada Masyarakat, (52).

Sukino. (2013). Membangun Pertanian dengan Pemberdayaan Masyarakat Tani Terobosan Menanggulangi Kemiskinan. Yogyakarta: Pustaka Baru Press.

Sumarlan. (2012). Peningkatan Kinerja Petani Sekitar Hutan dalam Penerapan Sistem Agroforestri Di Pegunungan Kendeng Pati. Jurnal Agro Ekonomi, Mei, 30(1), 25-39.

Suryono Haryono. (2013). Pemberdayaan Masyarakat di Era Global. Yogyakarta: Alfabeta.

Tahir dan Suddin. (2017). Analisis Pendapatan Usahatani Jagung Pada Lahan Sawah 
dan Tegalan di Kecamatan Ulaweng, Kabupaten Bones Sulawesi Selatan. Jurnal Galung Tropika, 6(1), 1-11.

Umbu Maramba. (2018). Pengaruh Karakteristik Terhadap Pendapat Petani Jagung Di Kabupaten Sumba Timur (Studi Kasus: Desa Kiritana, Kecamatan Kambera, Kabupaten sumba Timur). Jurnal Ekonomi Pertanian Dan Agribisnis (JEPA), 2(2), 94-101.

Undang-Undang Nomor 19 Tahun 2013 tentang Perlindungan dan Pemberdayaan Petani. (diaksespada 17 Februari 2019) 